\title{
Comic Media Assisted SQ3R Method Influence Students Comprehensive Reading Skills
}

\author{
Ni Putu Yasmita Dewi \\ Program Studi Pendidikan Guru Sekolah Dasar, FIP, Universitas Pendidikan Ganesha, Singaraja, Indonesia \\ Email:yasmitadewi745@gmail.com \\ Ni Nyoman Ganing \\ Program Studi Pendidikan Guru Sekolah Dasar, FIP, Univeristas Pendidikan Ganesha, Singaraja, Indonesia \\ Email: ninyoman.ganing@undiksha.ac.id \\ I Wayan Sujana \\ Program Studi Pendidikan Guru Sekolah Dasar, FIP, Universitas Pendidikan Ganesha, Singaraja, Indonesia \\ Email:iwayan.sujana@undiksha.ac.id
}

\author{
A R T I C L E I N F O \\ Article history: \\ 1 Mei 2020 Received in \\ revised form \\ 11 Juni 2020 \\ Accepted 10 Juli 2020 \\ Available online 25 Agustus \\ 2020 \\ Kata Kunci: \\ sq3r, keterampilan \\ membaca pemahaman, \\ komik \\ Keywords: \\ sq3r, comprehensive \\ reading skills, comic
}

\begin{abstract}
A B S T R A K
Keterampilan membaca pemahaman siswa yang belum optimal dan kegiatan pembelajaran yang kurang aktif dan menarik masih menjadi suatu permasalahan. Penelitian ini bertujuan untuk mengkaji pengaruh penerapan metode SQ3R berbantuan media komik terhadap keterampilan membaca pemahaman Bahasa Indonesia Kelas V. Desain Non Equivalen Controlgroup Design digunakan dalam penelitian ini. Populasi penelitian ini yaitu kelas V yang berjumlah 248 siswa dan diperoleh sampel pada kelompok eksperimen yaitu 35 siswa dan pada kelas kontrol 32 siswa. Pengumpulan data dalam penelitian ini dilakukan dengan menggunakan metode tes. Instrumen pengumpulan data yang digunakan berupa tes objektif pilihan ganda. Data yang dianalisis didapatkan thitun $=2,700>$ tabel $=1,997$ pada taraf signifikasi $5 \%(\mathrm{dk}=35+32-$ $2=65$ ) maka $\mathrm{H}_{0}$ ditolak dan $\mathrm{H}_{\mathrm{a}}$ diterima. Sehingga, dapat disimpulkan metode SQ3R berbantuan media komik berpengaruh terhadap keterampilan membaca pemahaman dalam pembelajaran Bahasa Indonesia Kelas V sehingga metode SQ3R berbantuan media komik dalam keterampilan membaca pemahaman baik diterapkan dalam kegiatan belajar Bahasa Indonesia.
\end{abstract}

\begin{abstract}
A B S T R A C T
This research is motivated by students' reading skills that are not optimal and learning activities are less active and interesting. This study was aimed at recognizing the influence of SQ3R comic assisted method application to the comprehensive reading skills in the learning process of Indonesian of the fifth grade. Quasi-experiment with a non-equivalent control group design was conducted in this study. The populations of this study involved 248 students and the obtained sample involved 35 students of the fifth grade from the experimental group and 32 students of the fifth grade from the control group. The data analysis was conducted by using t-test and the formula of polled variance. The analyzed data was obtained $\mathrm{t}_{\text {count }}=2.700>\mathrm{t}_{\mathrm{table}}=1.997$ at the significance level of $5 \%(\mathrm{df}=35+32-2=65) ; \mathrm{H}_{\mathrm{a}}$ was accepted and $\mathrm{H}_{0}$ was rejected which means there was a significant difference in reading comprehension skills between groups of students who were taught with the SQ3R method assisted by comic media and groups of students who were taught with conventional learning. Based on the explanation above, it can be concluded that the SQ3R method assisted comic effects the comprehensive reading skills in the learning process of Indonesian in the fifth grade. This research proves that the application of SQ3R method assisted by comic media in reading comprehension skills has a significant effect on Indonesian learning activities so that it affects students' reading comprehension skills in Indonesian.
\end{abstract}

\section{Introduction}

Indonesian is one of the subjects that must be taught in elementary schools. (Anzar \& Mardhatillah, 2018) state that Indonesian is a subject that can be studied directly in everyday life but not a few students consider Indonesian subject as a difficult subject. The difficulty in learning Indonesian has caused students to be less enthusiastic about receiving the subject matter. (Khair, 2018) states that Indonesian learning is essentially teaching students about proper and correct Indonesian skills based on their goals and functions. Indonesian teachers in SD (Elementary School) are expected to provide an interesting and fun learning atmosphere so students can learn Indonesian properly and correctly and do not experience difficulties in learning. Indonesian learning in SD aims to increase knowledge and skills in language. There are four skills in learning Indonesian in 
elementary school, namely listening, speaking, reading, and writing. (Atikah et al., 2017) states that one of the language skills that must be mastered by students is reading.

Reading is an activity of getting information. Reading is a process that is done by the reader to get message from the writer in his writing so that students know the purpose and content of the material (Marwati \& Basri, 2018; Fauziah 2018). In education, reading is important because all of the knowledge and information is received from reading activities. Reading skill is the key of students to deepen knowledge (Samhati et al., 2019). Reading skill is needed to be focused on understanding the text and students are trained intensively to understand the text. Reading comprehension is a type of reading activity in elementary school. Reading comprehension is students' ability to remember all the content of the text and train their ability in gathering the information from the text or story (Gunarsa et al., 2018; Budiarti \& Haryanto, 2016; Sundari, 2019; Abidin, 2016). In another word, reading comprehension is a complex activity that is not just recalling the writing but also visualize the written symbol to oral form and the process of thinking to get the meaning of the text.

Based on observations at Elementary School in Cluster Mengwi from $28^{\text {th }}$ to $29^{\text {th }}$ October 2019, the obtained information was that students' reading skills still need to be optimized. This can be seen from the odd semester Middle Semester Assessment (PTS), especially the Indonesian content of 248 students, as much as $50.80 \%$ of the student's score was below the KKM (minimum completeness criteria). The understanding of a reading and students' interest in reading was not optimal became the factor for students who get score under KKM. According to (Sati et al., 2015) without limited reading interest and skills elementary students become less aware of the reading material that they read so they have difficulty in understanding the content of the reading. Students consider reading activities is boring, especially with long reading. (Fatih, 2019) states that the teacher uses a less attractive method so that many students think that reading is boring. (Fauziah, 2018) teachers have an important role in the success of reading. (Khaerunnisa et al., 2018) state that students' reading comprehension ability is still low due to two factors, namely teacher factors and student factors. The teacher factors are: (1) The implementation of the strategies is less varied so that the learning process does not activate students; (2) The teacher does not use an attractive reading strategy in learning so that students feel bored. While student factors are : (1) Students have difficulty in answering questions that require understanding in their own words or questions that require reasoning; (2) students are less able to understand the reading text.

The described conditions above affect children's reading skills. The cooperation between teachers and students must be implemented in order to improve students' reading skills. To optimize students' reading comprehension skills in elementary school, one alternative that can be done is to apply one of the reading comprehension learning methods, namely the SQ3R method. (Najmawati, 2019) states that SQ3R model is a systematic and practical learning procedure. The SQ3R model is an excellent reading method for intensive and rational reading purposes. The SQ3R learning method is a learning method that focuses on efficient reading activities and helps students to concentrate more on the text being read so that it can encourage students to have better understanding from what they have read (Nugraheni \& Yunianta, 2018; Ardila et al. , 2019; Susanti and Yulita, 2016). It can be concluded that the SQ3R method is a designed learning method in such a way that students can understand the reading content in the Indonesian learning process. Besides the use of SQ3R learning method, an innovative and interesting media such as comic media can be used to overcome the problem of reading comprehension.

Comics are learning media in the form of picture collection and form of a story that is useful for conveying information. Comics are pictorial stories that provide information to readers. (Nugraheni, 2017) states that comic is a story presentation with an interesting and funny series of pictures. Comic books provide simple, easy-to-grasp, and understandable stories so they are very popular with both children and adults. (Sudjana \& Rivai, 2018) state that comics are a form of cartoon images that reveal characters and act out a story in a sequence that is closely related to images and provide entertainment to the readers. Prastowo in (Ariesta \& Kusumayati, 2018) states that comic media is a learning medium that is packaged in the form of pictorial stories to increase the clarity of concepts and construct students' knowledge. Based on these three opinions, it can be concluded that comic media is a learning medium that is packaged in the form of cartoon images that act out a particular story to provide knowledge to readers.

The SQ3R learning method can run effectively if its application is adjusted to the syntax or the learning steps are arranged systematically. (Putri, 2019) states that the steps of the SQ3R learning method consisted of 5 phases, namely 1) Survey: teacher informs students to pay attention to the titles written in the book, then directing students to read the text, and filtering important information from the text; 2) Question: teacher informs students to arrange the questions based on what has been obtained during reading, then the question is written on the blackboard; 3) Read: the teacher allows students to read again while paying attention to the compiled questions; 4) Recite: the teacher directs students to answer questions that have been written on the board; 5) Review: the teacher gives students the opportunity to re-read the text and review/improve the answers to these questions. 
The advantages of the SQ3R model includes namely, (1) involving students more directly and actively in the teaching and learning process; (2) easier to prepare, implement, and strengthen memory (Anjeli et al., 2020). It is in line with the opinion of Habeeb \& Abbas in (Yulia \& Sapto, 2019) which reinforces their statement that using the SQ3R method can make students active and directed readers with the subject of reading that is read and can strengthen students' memory. Students can strengthen their memory regarding the subject matter that has been studied if students have high enthusiasm for learning. The presented stories in the comics consist of pictures and reading which really helps students to avoid bored feeling in the learning process of reading skills because the images in comics can enliven the written text (Karmiani, 2018; Saputro \& Soeharto 2015). The SQ3R learning method assisted by comic media is very good to be applied in the teaching and learning process in elementary schools because students become more interested in reading and students' understanding increases.

Several relevant study results strengthen this present study, namely a study conducted by (Setiawan \& Yuliatin, 2018) which shows that the effect of implementing the SQ3R learning method (Survey, Question, Read, Recite and Review) combined with Snowball Throwing on student cognitive learning outcomes in the eye PPKn (Civics) lessons at SMP (Junior High School) Negeri 1 Mataram. The differences are in the dependent variable, place, and time of implementation and the grade level understudy. Furthermore, (Yulia et al., 2019) show that there is an effect of learning methods on learning outcomes in the fourth grade elementary school 1 Sumberagung. The differences are in the dependent variable, place, and time of implementation. (Jainah \& Hasanah, 2019) show that the SQ3R method can be used as an effort to improve reading comprehension skills. The differences are in terms of place and time of implementation as well as the grade level understudy. This present study is different from previous study since this study is innovated with the existence of comic media. This study aimed at determining the effect of the comic media assisted SQ3R method on reading comprehension skills of the fourth grade in Cluster IV, Mengwi District, academic year 2019/2020.

\section{Method}

This research was conducted in the fourth grade elementary school in cluster IV, Mengwi District which consisted of 8 schools, namely (1) SDN 1 Lukluk, (2) SDN 2 Lukluk, (3) SDN 3 Lukluk, (4) SDN 4 Lukluk, (5) SDN 1 Penarungan, (6) SDN 2 Penarungan, (7) SDN 3 Penarungan, and (8) SDN 4 Penarungan. The research implementation time was in the second semester of the academic year 2019/2020. This study was a quasiexperimental study with a non-equivalent post-test only control group design.

The population in this study was the fourth grade students, Cluster IV, Mengwi District, with a total of 248 students. The sample in this study was taken using random sampling techniques. The samples in this study were the fourth grade students of SD 1 Lukluk and SD 3 Lukluk. The implementation of this research consisted of three stages, namely, the preparation stage, the implementation stage, and the final stage. In the preparation stage for this experiment, the activities were: (1) Interviewing the Principal and the fourth grade teacher in Cluster IV Mengwi to determine equality in Elementary School in Cluster IV Mengwi, (2) Determining the class as the sample in the study, (3) ) RPP (lesson plan) was prepared using comic media assisted SQ3R learning method, (4) guidance of assessment instruments with the fourth grade teachers and lecturers, (5) lesson plan consultation with lecturers and the fourth grade teachers, (6) conducting instrument trials, (7) giving pretest to 2 sample classes, (8) determining the equality of the group by using the t-test technique, (9) conducting draw to obtain the experimental and control groups.

After obtaining the research sample, then equivalence of the sample group was determined by measuring the students' initial ability by conducting a pre-test on the two sample groups, then proceeding with an equivalence test. The pre-test data from the two groups must meet the normality test using the KolmogorovSmirnov technique and the variance homogeneity using Fisher's test $(\mathrm{F})$. The recapitulation of the normality test results of the research sample can be seen as follows.

Table 1. The Pre-test of Normality Test

\begin{tabular}{cccccl}
\hline No & Sample & Total & $\begin{array}{c}\text { Value } \\
\mid \text { Ft-Fs } \mid\end{array}$ & $\begin{array}{c}\text { Table Score of } \\
\text { Kolmogorov- } \\
\text { Sminov }\end{array}$ & Description \\
\hline 1 & Group I & 35 & 0.109 & 0.224 & Normally \\
2 & Group II & 32 & 0.113 & 0.234 & Distributed \\
\hline
\end{tabular}

On the other hand, the recapitulation of variance homogeneity test can be seen as follows. 
Table 2. The Recapitulation of Variance Homogeneity Test

\begin{tabular}{lllllll}
\hline No. & Sample & Variance & $\begin{array}{c}\text { Degree } \\
\text { of } \\
\text { Freedom }\end{array}$ & F count & F table & Description \\
\hline 1 & Group I & 6.887 & 34 & 1.034 & 1.810 & Homogeneous \\
\hline
\end{tabular}

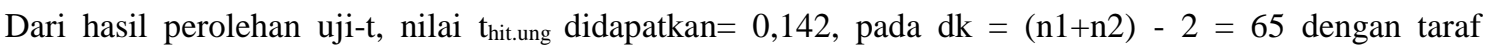
signifikansi $5 \%$ didapatkan $\mathrm{t}_{\text {tabe. }}=1,997$ sehingga $\mathrm{t}_{\text {hitung. }}<\mathrm{t}_{\text {tabel. }}$ maka Ho diterima, yang berarti kelompok sampel setara. Setelah kelompok kelas kedua sampel setara, dilanjutkan dengan pengundian kelompok kelas eksperimen serta kontrol dengan hasil kelas V SDNo. 1 Lukluk sebagai kelompok kelas eksperimen dan kelas V SDNo. 3 Lukluk sebagai kelompok kelas kontrol.

Based on the results of the analysis of the homogeneity test, it was obtained $F_{\text {count }}=1.034$, this price while the $\mathrm{F}_{\text {table }}$ price with dk counters $=35-1=34$ and dk denominator $=32-1=31$ at the $5 \%$ level, so that the $F_{\text {table }}=$ 1.810. Because the price of $\mathrm{F}_{\text {count }}<\mathrm{F}_{\text {table }}(1.034<1.810)$, the data variance from the pretest reading comprehension skills between grade five of SDN 1 Lukluk and SDN 3 Lukluk was homogeneous. To test the equality, t-test was conducted. The t-test was used to determine group equality with polled variance. It was because the number of samples was not the same and the variance was homogeneous.

From the results of the $\mathrm{t}$-test, the value of $\mathrm{t}_{\text {count }}$ was 0.142 , at $\mathrm{dk}=(\mathrm{n} 1+\mathrm{n} 2)-2=65$ with a significance level of $5 \%$ and obtained $t_{\text {table }}=1.997$ so that $t_{\text {count }}<t_{\text {table }}$, then Ho was accepted which means the sample group is equivalent. After the second group samples were equal, it was continued with the drawing of the experimental and control class groups with the results of fifth grade in SDN 1Lukluk as the experimental group and SDN 3 Lukluk as a control group.

Table 3. The Recapitulation of Equality Test

\begin{tabular}{cccccc}
\hline No. & Sample of study & $\mathbf{t}_{\text {count }}$ & Dk & $\mathbf{t}_{\text {table }}$ & Description \\
\hline 1 & The fifth grade of & & & & \\
& SD N 1 Lukluk & 0.142 & 65 & 1.997 & Equal \\
2 & $\begin{array}{l}\text { The fifth grade of } \\
\text { SD N 3 Lukluk }\end{array}$ & & & & \\
\hline
\end{tabular}

In the process of collecting data, the test method was used. In this study, an objective test in the form of multiple choice consisting of 4 choices ( $a, b, c$, or d) was the instrument. Multiple choice tests were based on a grid of arranged questions considering the basic competencies (KD) and indicators that are in line with the teacher manual and the material being studied and it was also guided by the existing curriculum foundation, namely the 2013 curriculum. Question items were made to measure students' reading comprehension skills that consisted of 50 items in the form of regular multiple choice. Before implementing the instrument, thee expert test was carried out first, the expert test was carried out by two experts (supervisors and homeroom teachers). Then the test instrument was tested for the validity of the item in question through several instrument tests. Testing of test instruments was done by trying out the test instruments (items) in the group that is higher than the sample class. The research instrument was tested through several stages, namely test-validity, difference power test, difficulty index, and reliability test. Based on the results of the instrument test, 50 items produced 30 valid items that could be used to measure students' reading comprehension skills. The provisions in giving a score, namely if the student answered correctly the test item got a score of 1 and the student answered incorrectly the test item got a score of 0 . Then, to get the final score, the obtained score was divided by the students' maximum score and multiplied by 100 , the student's final score with a scale of 100 was obtained.

Inferential statistical analysis was the statistic that was used to perform data analysis by making general conclusions. This statistic was suitable with the present study where it applied random sampling technique. If the data was normally distributed and the variance was homogeneous, then testing the hypothesis with the $\mathrm{t}$-test. $\mathrm{H}_{\mathrm{o}}$ was accepted and $H_{a}$ was rejected if $t_{\text {count }}<t_{\text {table }}$, and vice versa $H_{0}$ was rejected and $H_{a}$ was accepted if $t_{\text {count }}>$ $\mathrm{t}_{\text {table }}$ with a significance level of $5 \%$ with $\mathrm{d} \mathrm{k}=\mathrm{n}_{1}+\mathrm{n}_{2}-2$.

\section{Result and Discussion}

In this study, the fifth grade of SD N 1 Lukluk is an experimental group. After being given treatment by applying the SQ3R learning method assisted by comic media, and at the end of the experiment the post-test was 
given to students so that the reading skills data of Indonesian comprehension were obtained. Then, the normalized gain score data were obtained from the acquisition of pre-test and post-test values. The average gain score in reading comprehension skills of the experimental group students was 0.487 . The data variance of reading comprehension skills in the experimental group was 0.009 and standard deviation was 0.095 .

Table 4. The Recapitulation of Normalized Gain Score Data in Experimental Group

\begin{tabular}{cc}
\hline Mean & 0.487 \\
\hline Variance & 0.009 \\
Standard Deviation & 0.095 \\
\hline
\end{tabular}

In this study, the fifth grade of SD N 3 Lukluk was a control group. After being given a pretest, it was continued with the implementation of conventional learning as usual, at the end of the posttest experiment was given to students to obtain data. Then, the normalized gain score data was obtained from the pre-test and posttest results. It was obtained that the control group students' reading skills score was 0.433 . The data variance in the control group was 0.006 and a standard deviation was 0.077 .

Table 5. The Recapitulation of Normalized Gain Score Data in Control Group

\begin{tabular}{cc}
\hline Mean & 0.433 \\
\hline Variance & 0.006 \\
Standard Deviation & 0.077 \\
\hline
\end{tabular}

The highest Value |FT-Fs| from the results of the normality test in the experimental group data was 0.181 , this value was used as the normality test of the data distribution. The amount of data was 35 and with a significance level of $5 \%$, the value of the Kolmogorov-Smirnov test table was 0.224 . With these results, it is stated that $\mathrm{H}_{0}$ is accepted and $\mathrm{H}_{\mathrm{a}}$ is rejected so that the data is normally distributed.

Based on the results of the control group normality test, the highest value of | FT-Fs | was 0.108 , this value was used as the normality test of the data distribution. As for the amount of data as much as 32 and with a significance level of $5 \%$, the value of the Kolmogorov-Smirnov test table was 0.234 to obtain a comparison of the value of $\mid$ FT-Fs $\mid$ the largest $<$ the value of the Kolmogorov-Smirnov table, namely $0.108<0.234$.

Table 6. The Recapitulation Result of Normality Test

\begin{tabular}{cccccc}
\hline No. Sample Group & Total & $\begin{array}{c}\text { Value } \\
\mid \text { F t-F s } \mid\end{array}$ & $\begin{array}{c}\text { Table value of } \\
\text { Kolmogorov- } \\
\text { Smirnov }\end{array}$ & Description \\
\hline 1 & Experimental & 35 & 0.181 & 0.224 & Normally \\
2 & Control & 32 & 0.108 & 0.234 & Distributed \\
\hline
\end{tabular}

Based on the result of the test, $\mathrm{H}_{0}$ was accepted and $\mathrm{H}_{\mathrm{a}}$ was rejected. The result of the analysis test obtained $\mathrm{F}_{\text {count }}=1.50$ while $\mathrm{F}_{\text {table }}$ at a significant level of $5 \%$ with $\mathrm{dk}(34.31)$ and $\mathrm{F}_{\text {table }}$ was 1.81 . Thus, $\mathrm{F}_{\text {count }}<$

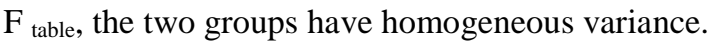

Table 7. The Recapitulation of Homegenety Test Result

\begin{tabular}{clccccc}
\hline No & Sample & Variance. & Dk & Fcount & Ftable & Description \\
\hline 1 & Experimental & 0.009 & 34 & 1.50 & 1.81 & Homogeneous \\
2 & Control & 0.006 & 31 & & & \\
\hline
\end{tabular}

Based on the data of normalized gain scores that are normally distributed and homogeneous variance, the $t_{\text {count }}$ score in this study was 2.700 and the score of $t_{\text {table }}$ was 1.997 so that $t_{\text {count }}$ was $2.700>t_{\text {table }}$ was 1.997 . Thus, the null hypothesis $\left(\mathrm{H}_{0}\right)$ is rejected. 
Table 8. The Recapitulation of T-test Analysis

\begin{tabular}{cccccccc}
\hline No & Sample & Total & Dk & $\bar{X}$ & $\mathbf{t}_{\text {count }}$ & $\mathbf{t}_{\text {table }}$ & Keterangan \\
\hline 1. & Experimental & 35 & 65 & 0.487 & \multirow{2}{*}{2.700} & 1.997 & $\begin{array}{c}\mathrm{H}_{0} \text { is } \\
\text { rejected }\end{array}$ \\
\hline
\end{tabular}

From the result of the t-test analysis, it showed that there was a significant difference in reading comprehension skills. This significant difference can be seen from the difference in the results of the analysis of the normalized average gain score of reading comprehension skills in Indonesian learning. The average gain score of the experimental group was $0.487>$ the average gain score of the control group was 0.433 . The different results of reading comprehension skills were obtained from the average score in the experimental group that was greater than the control group. The test results also showed that $t_{\text {count }}=2.70$ greater than $t_{\text {table }}=1.997\left(t_{\text {count }}>\right.$ $\left.\mathrm{t}_{\text {table }}\right)$. Thus, it can be concluded that the implementation of the comic media assisted the SQ3R method in reading comprehension skills is good to be applied in Indonesian learning activities so that it affects students' reading comprehension skills of Indonesian.

The success of this study was due to the treatment in the form of the comic media assisted SQ3R learning method given to the experimental group. The implementation of the comic media assisted SQ3R learning method has systematic steps that can help students understand the content of the reading, namely surveys, making questions, reading, reciting, and reviewing. According to (Anjeli et al., 2020) the advantages of this SQ3R learning model include more directed and active involvement of students in the teaching and learning process as well as it is easier to prepare, implement, and strengthen memory.

The first finding in learning with comic media assisted SQ3R learning method is that students have better understanding in reading. It can be seen through the SQ3R learning stages. At the survey stage, students get to know the writing organization and get a general impression of the book so that they can find out the contents of the entire reading. In the questions stage, students are given the opportunity by the teacher to ask questions and try to find answers to their questions by doing reading activities so that students understand what they are reading and make students think critically. This is supported by (Artu's et al., 2016) statement where at the initial stage students are directed to pay attention to the written titles on the board. Furthermore, students read the text in a few minutes at a glance to know the details of important information and outline the contents of the text before reading the text. The same thing is also stated by (Nurvicalesti et al., 2019) where the readers begin to research, review, explore at a glance to know the reading material that will be read in detail and based on the need so that the needed information is obtained during reading. At the recite stage, students repeat what they have read and presented the obtained answers so that students have a longer memory. Students are more interested in reading a comic during the teaching-learning process because they do not feel bored in reading. This is supported by the statement of (Nurvicalesti et al., 2019) states that the recite stage is the ability to restate/represent a problem. In addition, there is a statement quoted from (Artu, 2016) which states that at the recite stage, it directs students to answer questions that have been written on the board, questions whose answers are not yet correct are not immediately discussed completely by the teacher but the students are given the opportunity at the next stage to correct it through teacher guidance.

The second, students become more active and have a greater willingness to read. Because in the SQ3R model students are given a reading title that makes students interested in reading it. If students have finished reading the reading text, this model requires students to find questions on the reading content so that students cannot just read but must understand the content of the reading. As stated by (Rahmawati, 2018), providing reading and requiring students to look for questions is an activity to understand and think that occurs simultaneously so that reading in high classes occurs thinking activities to understand reading, not just learning letters or speech. The same thing is also conveyed by (Akmal \& Hasan, 2020) which state that asking students to make questions from the content of the reading will make students focused and reluctant to joke. Reading activities that can focus on students are through questions. If questions have been asked, students who are all less focused will pay attention to it because they have responsibility and competition with other students. In addition, students will be more critical in finding information in reading texts through questions. Moreover, (Budiarti \& Haryanto, 2016) state that reading comprehension activities will criticize students' ability to find reading information through pictures or questions. Thus, the SQ3R model requires students to seek questions from reading sources that can improve students' reading comprehension skills, especially in high class.

The third, the application of comic media assisted SQ3R learning model improve students' reading comprehension skills effectively. This is indicated by the students' enthusiasm in reading. (Fatih, 2019) states that students feel bored when the teacher uses an unattractive method in learning. It will make students lazy and reluctant to read. Students assume that reading activities are dull and often make students sleepy and feel lazy. However, the use of comic media assisted SQ3R model becomes something new for students. Reading is no 
longer boring, because comics will include funny pictures and characters that encourage students to read sustainability. As stated by (Suparman, 2020), learning using comic media will create a suitable learning atmosphere for children. Therefore, the use of the comic media assisted S3QR model is suitable to be applied in an elementary school environment.

Unlike the control group, students in the control group were taught with conventional learning. Conventional learning is learning that tends to be monotonous where the teacher only teaches what is in the book without any variation in the delivery of the material; it causes students bored when learning takes place in class. (Dewi et al., 2013) state that conventional learning is teacher-centered. The teacher plays a dominant role and students are not required to find the material. It tends to make students passive because they cannot expand and deepen their knowledge.

Based on the analysis test and theory presentation, the experimental group's reading comprehension skills of Indonesian are superior to the control group. This statement is supported by a relevant study from (Hastuti et al., 2019) with the results of their research, namely the application of the SQ3R method can improve students' reading comprehension skills and a study conducted by (Yulia et al., 2019) shows that there is an effect of learning methods on learning outcomes of the fourth grade elementary school 1 Sumberagung.

Based on the findings of the study, the implementation of the SQ4R method has a positive impact and can improve students' reading comprehension skills. The implication of comic media assisted SQ3R method is that this method is the right method and suitable to be applied in the learning process because it can influence students' reading skills. This study proves that the comic media assisted SQ3R method is good and appropriate to be applied in learning activities and can make teaching and learning activities interesting so that it affects students' reading comprehension skills more optimally. Whereas in practical implications, the comic media assisted SQ3R method can be used as a reference for teachers in determining various methods and learning media that can be used as an option for determining learning strategies because the comic media assisted SQ3R method has proven to increase students' reading interest and understanding. The implementation of SQ3R method makes students' reading comprehension meaningful, not only knowing or memorizing the content of the reading but really understanding the meaning and purpose of the reading. In this regard, the SQ3R method is very suitable to be applied in elementary schools.

\section{Conclusion}

Based on the data analysis, the average of normalized gain score reading comprehension skills in the experimental group students is greater than the average of reading comprehension skills in the control group. From the results of the hypothesis test analysis, it is stated that there is a significant difference in the gain of normalized scores from the two groups. The comic media assisted SQ3R method is good and appropriate in learning activities and can make teaching and learning activities interesting and directed so that it affects students' reading comprehension skills more optimally. Thus, it can be concluded that comic media assisted the SQ3R method influences reading comprehension skills in learning Indonesian of the fifth grade elementary school in Cluster IV, Mengwi District, Academic Year 2019/2020.

\section{References}

Abidin, Y. (2016). Pembelajaran Membaca Berbasis Pendidikan Karakter. PT Refika Aditama.

Akmal, N., \& Hasan, S. (2020). Penerapan Model Survey Question Read Recite Review Sq3r Dalam Pembelajaran Ipa Di Smp. Jurnal Biology Education, 8(1).

Anjeli, Meiliawati, R., \& Fatah, A. H. (2020). Pemahaman Konsep Minyak Bumi Hasil Pembelajaran Menggunakan Model Kooperatif Tipe SQ3R Di SMA Negeri 4 Palangka Raya Tahun Ajaran 2017/2018. Jurnal Ilmiah Kanderang Tingang, 11(1), 193-199.

Anzar, S. F., \& Mardhatillah, M. (2018). Analisis Kesulitan Belajar Siswa Pada Pembelajaran Bahasa Indonesia di Kelas V SD Negeri 20 Meulaboh Kabupaten Aceh Barat Tahun Ajaran 2015/2016. Bina Gogik: Jurnal Ilmiah Pendidikan Guru Sekolah Dasar, 4(1).

Ardila, R., Hidayat, M. T., \& Hidayah, L. W. (2019). Peningkatan Kemampuan Membaca Intensif Melalui Metode Sq3R Mahasiswa Perikanan Universitas Islam Madura. Journal of Language, Literature, and Teaching, 1(3), 64-79. https://doi.org/10.35529/jllte.v1i3.64-79

Ariesta, F. W., \& Kusumayati, E. N. (2018). Pengembangan Media Komik Berbasis Masalah Untuk Peningkatan Hasil Belajar IPS Siswa Sekolah Dasar. Pendas: Jurnal Ilmiah Pendidikan Dasar, 3(1), 22-33. 
Artu, N. (2016). Upaya Meningkatkan Kemampuan Membaca Pemahaman Siswa Kelas IV SDN Pembina Liang Melalui Penerapan Strategi Survey Questions Reading Recite Review (SQ3R). Jurnal Kreatif Online, 2(2).

Atikah, I., Iswara, P. D., \& Hanifah, N. (2017). Penerapan Metode Survey, Question, Read, Recite, Review ( Sq3R ) Dengan Permainan “ Pos Pelangi ” Untuk Meningkatkan. Jurnal Pena Ilmiah, 2(1), 36-37.

Budiarti, W. N., \& Haryanto, H. (2016). Pengembangan media komik untuk meningkatkan motivasi belajar dan keterampilan membaca pemahaman siswa kelas IV. Jurnal Prima Edukasia, 4(2), 233-242

Dewi, N. L., Dantes, N., \& Sadia, I. W. (2013). Pengaruh model pembelajaran inkuiri terbimbing terhadap sikap ilmiah dan hasil belajar IPA (Doctoral dissertation, Ganesha University of Education).

Fatih, M. (2019). Peningkatan Membaca Pemahaman melalui Strategi Direct Reading Thingking Activities ( DRTA ) Siswa Kelas VA SDN Bendogerit 1 Kota Blitar. 3(1), 28-34.

Fauziah, H. (2018). Upaya Guru dalam Mengembangkan Kemampuan Membaca Menulis Permulaan Siswa Kelas I MI. Elementary: Jurnal Ilmiah Pendidikan Dasar, 4(2), 173-184.

Gunarsa, I. M. D., Sudarma, D. I. K. ., \& Dibia, I. K. (2018). Pengaruh Strategi Sq4R Berbantuan Satua Bali Terhadap Kemampuan Membaca Pemahaman Siswa Kelas V. MIMBAR PGSD Undiksha, 6(1), 10-19. https://doi.org/10.23887/jjpgsd.v6i1.12920

Hastuti, D., Studi, P., Bahasa, P., Sastra, D. A. N., Pendidikan, J., Dan, B., Keguruan, F., \& Ilmu, D. A. N. (2019). Artikel Penelitian Pemahaman Menggunakan Metode Sq3r Pada Siswa.

Jainah, E., Yarmi, G., \& Hasanah, U. (2019). Peningkatan Kemampuan Membaca Pemahaman Melalui Metode Sq3r (Survey Question Read Recite Review) Pada Siswa Kelas V Sekolah Dasar Negeri Keagungan 05 Pagi Jakarta Barat. Dinamika Bahasa Sekolah Dasar, 1(1), 1-11.

Karmiani, S. (2018). Penggunaan Media Komik Berbahasa Inggris Sebagai Upaya Meningkatkan Kemampuan Membaca Pemahaman Bahasa Inggris Pada Siswa Kelas Viii Smpn 3 Teluk Kuantan. JURNAL PAJAR (Pendidikan Dan Pengajaran). https://doi.org/10.33578/pjr.v2i6.6514

Khaerunnisa, Salam, R., \& Astuti, U. (2018). Question Reading Recite Indonesian Educational Studies ( Ijes ). Indonesian Journal of Educational Studies, 21(1), 11-25.

Khair, U. (2018). Pembelajaran Bahasa Indonesia dan Sastra (BASASTRA) di SD dan MI. AR-RIAYAH: Jurnal Pendidikan Dasar, 2(1), 81.

Laily, I. F. (2014). Hubungan kemampuan membaca pemahaman dengan kemampuan memahami soal cerita matematika sekolah dasar. Eduma: Mathematics Education Learning and Teaching, 3(1).

Najmawati, N., Ibrahim, M. M., \& Ismail, W. (2019). Perbandingan Model Pembelajaran Circ Dan Sq3r Terhadap Hasil Belajar Peserta Didik Kelas VIII SMPN 4 Tombolo'pao. Al-Ahya: Jurnal Pendidikan Biologi, 1(2), 1-22.

Nugraheni, N. (2017). Penerapan Media Komik Pada Pembelajaran Matematika Di Sekolah Dasar. Refleksi Edukatika: Jurnal Ilmiah Kependidikan, 7(2)

Nurvicalesti, N., Dewi, N. R., \& Walid, W. (2019, February). Kemampuan Literasi Matematika pada Pembelajaran Survey, Question, Read, Reflect, Recite, Review (SQ4R) berpendekatan Realistik. In PRISMA, Prosiding Seminar Nasional Matematika (Vol. 2, pp. 103-108).

Prihanto, D. A., \& Yunianta, T. N. H. (2018). Pengembangan Media Komik Matematikapada Materi Pecahan Untuk Siswa Kelas V Sekolah Dasar. MAJU: Jurnal Ilmiah Pendidikan Matematika, 5(1).1121

Putri, A. R. (2019). Perbedaan Model Pembelajaran Pq4r Dan Sq3r Terhadap Hasil Belajar Siswa Kelas Iv Di Sd Gugus Diponegoro Pada Tema Indahnya Keragaman Di Negeriku. e-Jurnal Mitra Pendidikan, 3(3), 388401.

Rahmawati, A. (2016). Penerapan Sq3r Berbantunan Reka Cerita Gambar Untuk Meningkatkan Pemahaman Membaca Dan Hasil Belajar Siswa. Jurnal Profesi Pendidikan Dasar, 3(2), 127-133.

Saputro, H. B., \& Soeharto, S. (2015). Pengembangan media komik berbasis pendidikan karakter pada pembelajaran tematik-integratif kelas IV SD. Jurnal Prima Edukasia, 3(1), 61-72.

Setiawan, A., Ismail, I., \& Yuliatin, Y. (2018). Pengaruh Metode Pembelajaran SQ3R (Survey, Question, Read, Recite and Review) berpaduan Snowball Throwing terhadap Hasil Belajar Siswa pada Mata Pelajaran 
PPKn di SMPN 1 Mataram. Jurnal Pendidikan Sosial Keberagaman, 5(2).

Suparman, I. W., Eliyanti, M., \& Hermawati, E. (2020). Pengaruh Penyajian Materi Dalam Bentuk Media Komik Terhadap Minat Baca Dan Hasil Belajar. Pedagogi: Jurnal Penelitian Pendidikan, 7(1).

Susanti, S., \& Yulita Dewi Purmintasari, S. (2016). Pengaruh Penerapan Metode Pembelajaran SQ3R (Survey, Question, Read, Recite, And Review) Terhadap Hasil Belajar Mahasiswa Prgram Studi Pendidikan Sejarah IKIP PGRI Pontianak. Edukasi: Jurnal Pendidikan, 13(1), 97-104.

Yulia, D. S. F., Wahjoedi, W., \& Sapto, A. (2019). Pengaruh Metode Pembelajaran SQ3R terhadap Hasil Belajar Bahasa Indonesia. Jurnal Pendidikan: Teori, Penelitian, dan Pengembangan, 4(6), 808-814. 